\title{
Koroner Arter Bypass Cerrahisinde Kardiyopulmoner Bypass İlişkili Erken Dönem İnflamatuar Yanıt ve Yoğun Bakım Kalış Süresi Üzerine Atorvastatinin Etkileri
}

\author{
The Effects of Atorvastatin on Cardiopulmonary Bypass Induced \\ Inflammatory Response of Early Period and Intensive Care Unit Length of \\ Stay After Coronary Artery Bypass Surgery
}

\author{
Coşkun Araz, Arash Pirat, Adnan Torgay, Muammer Yücel*, Gülnaz Arslan \\ Başkent Üniversitesi Tıp Fakültesi Anesteziyoloji Anabilim Dalı, Ankara, Türkiye \\ *Başkent Üniversitesi Tıp Fakültesi, Biyokimya Anabilim Dalı, Ankara, Türkiye
}

\section{ÖZET}

Amac: Koroner arter bypass cerrahisi öncesi atorvastatin kullanımının, kardiyopulmoner bypass ile ilişkili erken dönem inflamatuar yanıta etkisinin değerlendirilmesi.

Gereç ve Yöntem: Hastanemiz Araștırma ve Etik Kurulları onayı ve yazılı olarak bilgilendirilmiş hasta onayları alındıktan sonra, atorvastatin kullanmakta olan (Grup S) ve kullanmayan (Grup K) 20'şer hasta prospektif olarak, vaka kontrol calıșması düzeninde calıșmaya alındı. Tüm hastalara standart anestezik ve cerrahi teknikler uygulanarak KPB eşliğinde KABG yapıldı. Hastalardan ameliyat başlangıcında (T1), aort klempi kalktıktan 5 dakika sonra (T2). KPB sonlandırldıktan 10 dakika sonra (T3) ve postoperatif 6. saat (T4) kan örnekleri alınarak interlökin-1 (IL-1), IL-6, tümör nekroz faktörü-alfa (TNF-alfa) ve p-selektin düzeyleri ölçüldü.

Bulgular: Demografik ve preoperatif özellikler; KPB, aort klempi ve anestezi süreleri; intra- ve postoperatif hemodinamik parametreler; inotrop ve vazopresör ihtiyaçları; kan ürünleri ve sıvı gereksinimleri ve ekstübasyon zamanları bakımından gruplar arasında anlamlı fark saptanmadı (tüm değerler için $p>0,05$ ). Serum IL-1, IL-6, TNF-alfa ve p-selektin seviyeleri, aort klempi kalktiktan 5 dakika sonra, KPB sonlandirıldıktan 10 dakika sonra ve postoperatif 6 . saatte bazal değerlerden anlamlı olarak yüksek bulundu $(p<0,05)$. Ancak, KPB ilişkili inflamatuar yanıt açısından, hiçbir ölçüm zamanında iki grup arasında anlamlı fark gözlenmedi $(p>0,05)$. Atorvastatin grubunda kontrol grubuna göre yoğun bakımda kalış süreleri anlamlı şekilde kısa bulundu (sırasıyla, $56,7 \pm 19,5$ saat ve $72,5 \pm 26,6$ saat, $p=0,008$ ).

Sonuc: Calıșmamızda, preoperatif atorvastatin kullanan KABG hastalarında KPB'a bağlı inflamatuar yanıt azalmadı. Ancak, atorvastatin kullananlarda yoğun bakım sürelerinin anlamlı derecede kısa bulunmasının, ileri calıșmalara olan ihtiyacı vurguladığı kanaatindeyiz. (Türk Yoğun Bakım Derneği Dergisi 2011; 9: 1-7)

Anahtar Kelimeler: Atorvastatin, kardiyopulmoner bypass, inflamatuvar yanit

\section{SUMMARY}

Objective: To evaluate the effects of preoperative using of atorvastatin on cardiopulmonary bypass induced early inflammatory response in coronary artery bypass grafting surgery.

Materials and Methods: After obtaining Instutitional Ethics Committee approval and patients' written informed consent, 20 patients who were atorvastatin users and 20 matched controls were included in this prospective observational cohort study. All patients underwent $C A B G$ with $C P B$ using standard anesthetic and surgical techniques. Blood samples were collected for measurement of serum interleukin-1 (IL-1), IL-6, tumor necrosis factor-alpha (TNFalpha) and p-selectin levels at the beginning of the operation (T1), 5 minutes after the removing of the cross clamp (T2), 10 minutes after the end of the CPB (T3) and 6 hours of the operation (T4).

Results: The groups were comparable regarding demographic features: preoperative characteristics: duration of $\mathrm{CPB}$ aortic cross clamping, and anesthesia; intra- and postoperative hemodynamic parameters; inotrope and vasopressor needs; blood products and fluid requirements; and extubation times ( $p>0.05$ for all). Compared to baseline values, in both groups serum IL-1, IL-6, TNF-alpha and p-selectin levels increased significantly at the 5 minutes after the opening of the cross clamp, termination of CPB and 6 hours after surgery ( $p<0.05$ for all). However, there were no significant differences between the two groups at any measurement time point in terms of CPB induced inflammatory response ( $p>0.05$ for all). Patients in atorvastatin group had a significantly shorter intensive care unit (ICU) length of stay than the control group $(56.7 \pm 19.5$ hours vs $72.5 \pm 26.6$ hours, $P=0.008)$.

Conclusion: Pretreatment with atorvastatin did not decrease CPB induced inflammatory response in our CABG patients. The shorter length of ICU stay in our atorvastatin users needs to be further evaluated. (Journal of the Turkish Society of Intensive Care 2011; 9: 1-7) Key words: Atorvastatin, cardiopulmonary bypass, inflammatory response

Yazışma Adresi/Address for Correspondence: Dr. Coşkun Araz, Başkent Üniversitesi Anesteziyoloji Anabilim Dalı, Ankara, Türkiye

Tel.: +90 31221268 68-1172-1173 Faks: +90 3122121583 E-posta: arazcoskun@yahoo.com Gelis Tarihi/Received: 03.12.2010 Kabul Tarihi/Accepted: 15.04.2011 TARK 2010'da sözlü olarak sunulmuştur. Ocak 2011'de Society of Critical Care Medicine $40^{\text {th }}$ Annual Meeting kapsaminda poster bildirisi olarak San Diego'da sunulmuștur. 


\section{Giriş}

Kardiyopulmoner bypass (KPB), kalp cerrahisi ameliyatlarında cerrahi müdahalenin kolaylaştırılması ve daha etkin bir girişim sağlanabilmesi amacıyla sıklıkla kullanılan bir yöntemdir. Ancak bu yöntem kompleman sistemi, sitokinler, koagülasyon-fibrinoliz kaskadı, endotel ve hücresel immün sistem gibi birçok yolak üzerinden sistemik inflamatuar yanıt sendromu (systemic inflammatory response syndrome, SIRS) oluşmasını tetikler. Cerrahi işlem, kan elemanlarının KPB pompa sisteminin iç yüzeyi ile teması, iskemi/reperfüzyon (l/R) hasarı, hipotermi, endotoksemi, cerrahi stres ve anestezi SIRS tablosunun nedenlerindendir $(1,2)$. Bu inflamatuar yanıt postoperatif dönemde oluşabilecek miyokard disfonksiyonu, solunum yetmezliği, renal ve nörolojik bozukluklar, kanama diyatezi, karaciğer fonksiyon bozukluğu ve hatta çoklu organ yetmezliği (multiple organ failure, MOF) gibi komplikasyonlar ile ilişkili olabilir (1,3-6). Bu nedenle pratikte KPB ile oluşan bu olumsuz inflamasyonun önlenmesine yönelik mekanik ve/veya farmakolojik birçok yöntem kullanılmaktadır $(3,7,8)$.

Statinler, 3-hidroksi-3-metilglutaril-koenzim A redüktaz enzimini inhibe ederek kandaki düşük dansiteli lipoprotein (low density lipoprotein, LDL) seviyesini düşürürler. Ek olarak "pleiotropik etki" olarak da bilinen ve vaskülogenez, immünomodülasyon, lökosit adezyonunun önlenmesi, antiinflamasyon, monosit kemotaktik faktör1, trombosit aktive edici faktör, lökotrien B4, $\beta$-2 integrin ve lökosit fonksiyon ilişkili antijen-1 azalması gibi henüz tam olarak açıklığa kavuşmamış olan birçok ek özelliklerinin varlığı bilinmektedir (9-11). Bu ilaçlar ile kardiyovasküler olaylara ikincil gelişebilen ölüm, miyokard infarktüsü (MI), serebrovasküler olay (SVO), renal disfonksiyon gibi komplikasyonlarda azalma sağlanmıştır (12). Ayrıca deneysel ve klinik çalışmalarda, koroner revaskülarizasyon ameliyatlarından önce kısa süreli dahi olsa statin kullanımasının miyokard fonksiyonu ve greft açıklığını olumlu yönde etkilediği, tekrarlayan iskemik atakları azalttığı ve tekrar revaskülarizasyon gereksinimini ve mortaliteyi düşürdüğü gösterilmiştir (12-15).

Çalışmamızda, preoperatif atorvastatin kullanılmasının, bir l/R ve artmış inflamatuar yanıt modeli olan kardiyopulmoner bypassta oluşan inflamasyona ve kardiyak, serebral, pulmoner ve renal sistemler üzerine etkilerini incelemeyi amaçladık.

\section{Gereç ve Yöntem}

Hastanemiz Klinik Araştırma ve Etik Kurulları onayı (KA04/144) ve bilgilendirilmiş hasta onayları yazılı şekilde alınarak, koroner arter bypass greftleme (KABG) cerrahisi geçirecek olan hastalar, atorvastatin kullananlar (Grup S, $n=20$ ) ve statin kullanmayanlar (Grup $K, n=20$ ) olmak üze- re iki grupta, prospektif olarak vaka-kontrol düzeninde çaışmaya dahil edildi. Yakın zamanda geçirilmiş infeksiyon, ejeksiyon fraksiyonunun <\%35 olması, geçirilmiş toraks veya kalp cerrahisi, acil cerrahi, sistemik inflamatuar hastalıklar, preoperatif karaciğer fonksiyon testlerinde iki kattan fazla yükseklik, geçirilmiş SVO, klinik belirti ve bulguya neden olan hepatik, renal, pulmoner veya serebral hastalıkların varlığı, eş zamanlı kapak cerrahisi planlanmaSı ve preoperatif dönemde sedimantasyon ve/veya C-reaktif protein (CRP) yüksekliği çalışma dışı bırakılma kriterleri olarak kabul edildi. Ayrıca, revizyon cerrahisi gereken hastalar ve Grup S'den 1 ve Grup K'dan 2 hasta olmak üzere toplam 3 hasta postoperatif dönemde çok fazla miktarda kristalloid ve kolloid sıvı alması nedeniyle, inflamatuar parametrelerin düzey standardizasyonunu bozmaması için çalışma dışı bırakıldı. Her iki gruptaki hastalara standart preoperatif hazırlık yapıldı. Grup S'deki hastalarda son dozu premedikasyon sırasında alınmak üzere preoperatif atorvastatin tedavisine devam edildi.

Rutin intraoperatif monitorizasyonu (EKG, nabız oksimetresi ve non-invaziv arteriyel kan basıncı) takiben etomidat (Etomidate Lipuro ${ }^{\circledR}$ ) 0,1-0,3 mg/kg IV, fentanil sitrat (Fentany $\left.{ }^{\circledR}\right) \quad 5-10 \mathrm{mcg} / \mathrm{kg}$ ve veküronyum bromür (Norcuron ${ }^{\circledR}$ ) 0,1 mg/kg IV ile anestezi indüksiyonu yapıdı. Anestezi idamesinde, fentanil sitrat $15 \mathrm{mcg} / \mathrm{kg} / \mathrm{st}$ ve $\% 40$ oksijen ile \%60 hava karışımı içinde izofluran (Forane ${ }^{\circledR)} \%$ 0,5-1,5 kullanıldı. Hastalar, volüm kontrol modunda tidal volüm 6-8 $\mathrm{mL} / \mathrm{kg}$ ve inspirasyon:ekspirasyon oranı 1:2 olacak şekilde, $0-5 \mathrm{cmH}_{2} \mathrm{O}$ PEEP uygulanarak ventile edildi. Solunum sayısı end-tidal $\mathrm{CO}_{2}$ değeri 30-40 $\mathrm{mmHg}$ olacak şekilde ayarlandı. Invaziv arteriyel kan basıncı ve santral venöz basınçlar izlendi, bazal aktive edilmiş pıhtılaşma zamanı (activated clotting time, ACT) ve arteriyel kan gazı örneklemeleri yapıldı. Ayrıca nazogastrik sonda ile mide dekompresyonu sağlandı. Idrar sondası ve sıcaklık takibi için nazofaringeal ve rektal problar yerleştirildi. Intraoperatif ortalama kan basıncı bazal kan basıncı $\pm \% 20$ olacak şekilde dopamin (Dopamine Fresenius ${ }^{\circledR}$ ) veya nitrogliserin (Perlinganit ${ }^{\circledR}$ ) dozları ayarlandı. Tüm hastalarda santral venöz basınç 6-10 mmHg olacak şekilde 500 mL kolloid (Gelofusine ${ }^{\circledR}$ ) ve laktatlı Ringer solüsyonu infüzyonu yapıldı. Antikoagülasyon, heparin (Nevparin $\left.{ }^{\circledR}\right)$ ( $4 \mathrm{mg} / \mathrm{kg}$, IV) ile yapıldı. Aort kanülasyonu, venöz kanülasyon ve kardiyopleji kanülünün konmasını takiben, ACT >450 saniye olduğunda KPB başlatıldı. Pompa prime solüsyonu hastanın hematokrit değeri \%26-28 olacak şekilde laktatlı Ringer, jelatin bazlı kolloid (Gelofusine ${ }^{\circledR}$ ), taze donmuş plazma, taze tam kan ve heparin ile hazırlandı. KPB başlangıcında pompa rezervuarına sodyum tiyopental (Pental ${ }^{\circledR}$ ) $3-5 \mathrm{mg} / \mathrm{kg}$, midazolam $0,1 \mathrm{mg} / \mathrm{kg}$ (Dormicum ${ }^{\circledR}$ ), metilprednizolon $5 \mathrm{mg} / \mathrm{kg}$ (Prednol $L^{\circledR}$ ) ve veküronyum bromür (Norcuron ${ }^{\circledR}$ ) 0,05 mg/kg eklendi. Sistemik hipotermi, vücut sıcaklığı $28-30^{\circ} \mathrm{C}$ olacak şekilde eksternal (su blanketi) ve internal (KPB) so- 
ğutma ile sağlandı. Membran oksijenatör (Cobe ${ }^{\circledR}$ Optima ${ }^{\circledR}$ XPTM) kullanılan KPB esnasında, alfa-stat $\mathrm{pH}$ stratejisi uygulandı ve pompa akım hızı ortalama arteriyel basınç 55-65 mmHg olacak şekilde ayarlandı. Aort klemplenmesini takiben miyokardın korunması, soğuk potasyumlu kristalloid kardiyopleji $(10 \mathrm{~mL} / \mathrm{kg}$ ) ve topikal soğutma ile sağlandı. KPB süresince ortalama kan basıncı stabil kalacak şekilde vazodilatör ve vazopresörler kullanıldı. Yeniden ısınma döneminde sodyum tiyopental 3-5 $\mathrm{mg} / \mathrm{kg}$, midazolam $0,1 \mathrm{mg} / \mathrm{kg}$ ve veküronyum bromür $0,05 \mathrm{mg} / \mathrm{kg}$ tekrar verildi. Distal anastomozlar tamamlandıktan ve kalp çalıştıktan sonra cerrahi stabilizasyonun ve yeterli hemodinamik istikrarın sağlanması, vücut sıcaklığının $37^{\circ} \mathrm{C}$ olması, elektrolit, kan gazı, ve hematokrit değerlerinin kabul edilebilir sınırlarda olması halinde KPB sonlandırıldı. Heparin antagonizasyonu, protamin (Protamin ${ }^{\circledR}$ ) ile (1 mg heparin için 1-1,2 mg olacak şekilde) gerçekleştirildi. Ameliyat boyunca yapılan monitörizasyon verileri, kullanılan tüm ilaç ve sıvı verilerinin hepsi 5'er dakika ara ile kaydedildi. Tüm hastalara standart cerrahi teknik uygulandı. Ameliyatı tamamlanan hastalar, kanama kontrolü ve hemodinamik stabilizasyon sağlanınca ekstübe edilmeden yoğun bakıma alındı.

Hastaların serebral fonksiyonlarının değerlendirilmesi amacıyla ameliyat öncesi ve sonrası nörolojik muayeneleri yapıldı, preoperatif ve postoperatif 3. gün mini mental test [16] uyguland. Rutin biyokimya testleri (glukoz, sodyum, potasyum, klor, kalsiyum, magnezyum, fosfor, alanin aminotransferaz (ALT), aspartat aminotransferaz (AST), alkalen fosfataz (ALP), gama glutamil transferaz (GGT), total ve direkt bilirubin, kan üre azotu (blood urea nitrogen, BUN), total protein, albümin, C-reaktif protein, sedimantasyon, protrombin zamanı, INR ve aktive edilmiş tromboplastin zamanı) ve tam kan sayımına ek olarak, böbrek fonksiyonlarının değerlendirilmesi için BUN ve kreatinine ek olarak 12 saatlik idrarda kreatinin klirensi ve mikroalbüminüri bakıldı. Hepatik fonksiyonların değerlendirilmesi için laboratuvar testleri baz alınırken, kardiyak fonksiyonların değerlendirilmesinde pozitif inotropik ajan gereksinimi, postoperatif 1. gün yapılan ekokardiyografi, preoperatif ve postoperatif 12. saat CK-MB (kreatin fosfokinaz MB) ve troponin I düzeylerinden yararlanıldı.

Hastalar, yoğun bakıma alınmalarını takiben hemodinamik yönden stabil olmaları (cerrahi sahadan aktif kanama düşünülmemesi, >10 mcg/kg/dakika pozitif inotrop gereksinimi olmaması, hemoglobin ve hematokrit seviyelerinin stabil seyretmesi), torakal drenajın olmaması (ilk gün için $\geq 100 \mathrm{~mL} /$ saat), oksijenasyonun normal olması (\% $40 \mathrm{FiO}_{2}$ ile $\mathrm{pO}_{2}>100 \mathrm{mmHg}$ olması) ve ventilatör desteğine gerek duyulmaması halinde ekstübe edildi. Yoğun bakım takibinde stabil olarak izlenen hastalar toraks drenajının olmaması (>200mL/gün), idrar çıkışının normal olması ( $\leq 1 \mathrm{~mL} / \mathrm{saat}$ ), spontan solunumla yeterli oksijenasyonun sağlanabilmesi (\%20-35 $\mathrm{FiO}_{2}$ ile $\mathrm{pO}_{2} \geq 85 \mathrm{mmHg}$ ), bilinç ve nörolojik problemlerinin bulunmaması ağrı stabilizasyonunun sağlanmasının ardından servise alındı.

Inflamatuar yanıtı değerlendirmek için santral venöz kateter takıldıktan 5 dakika sonra (T1), aort klempinin kalkmasından 5 dakika sonra (T2), KPB'nin sonlandırılmasından 10 dakika sonra (T3) ve ameliyat sonlandıktan 6 saat sonra (T4) olmak üzere 4 farklı zamanda kan örnekleri düz tüplere alındı. Bu kanlar 3000 devir/dakika hızla 5

Tablo 1. Grupların demografik özellikleri, sistemik hastalıkları, preoperatif dönemde kullandıkları ilaçlar (sayı veya ortalama \pm SD minimum-maksimum)

\begin{tabular}{lccc} 
& Grup K (n=20) & Grup S (n=20) & p \\
\hline Yaş (yıl) & $60,9 \pm 10,0(41-76)$ & $61,2 \pm 10,1(45-79)$ & 0,914 \\
Ağırlık (kg) & $80,3 \pm 11,4(60-104)$ & $76,8 \pm 10,8(51-92)$ & 0,313 \\
Boy (cm) & $170,5 \pm 8,6(150-185)$ & $165,6 \pm 8,3(151-180)$ & 0,066 \\
Cinsiyet (kadın/erkek) & $6 / 14$ & $9 / 11$ & 0,392 \\
Preoperatif MMT Skoru & $8,87 \pm 1,32(5-10)$ & $9,30 \pm 0,80(8-10)$ & 0,298 \\
Sistemik Hastalıklar & & & 0,527 \\
Hipertansiyon & $10 / 20$ & $12 / 20$ & 0,252 \\
Diabetes Mellitus & $7 / 20$ & $4 / 20$ & 0,175 \\
KOAH & $2 / 20$ & $0 / 20$ & 0,702 \\
Preoperatif Kullanılan Ilaçlar & & & 0,702 \\
Kalsiyum Kanal Blokörü & $8 / 20$ & $1 / 20$ & 0,536 \\
$\beta$-Blokör & $11 / 20$ & $1 / 20$ & 0,353 \\
ACE Inhibitörü & $5 / 20$ & $3 / 20$ & 0,850 \\
Oral Antidiyabetik & $6 / 20$ & $6 / 20$ & 0,601 \\
Insülin & $3 / 20$ & $7 / 20$ & \\
Sigara Kullanımı & $5 / 20$ & & \\
KOAH: Kronik obstrüktif akciğer hastalığı, ACE: Anjiyotensin dönüştürücü (converting) enzim, MMT: Mini mental test & \\
& & &
\end{tabular}


dakika süreyle santrifüj edilerek plazmalar ayrıldı ve numuneler $-70^{\circ} \mathrm{C}$ 'de saklandı. IL-1, IL-6, TNF-alfa ve p-selektin düzey ölçümleri enzyme-linked immunosorbent assay (ELISA) yöntemi ile gerçekleştirildi.

Hastaları yoğun bakıma çıkaran, yoğun bakımda takibini yapan ve yoğun bakımdan servise çıkışına karar verenlerden hiçbirisi gruplardan haberdar değildi. Postoperatif sıvı idamesinde santral venöz basınç 6-10 $\mathrm{mmH}_{2} \mathrm{O}$ ve ortalama arteriyel kan basınçları, bazal ortalama arteriyel basınç $\pm \% 20$ ve sistolik arteriyel basınç $>100 \mathrm{mmHg}$ olacak şekilde idame ettirildi. Ameliyat sonrasında hastaların rutin biyokimya, tam kan sayımı, 12 saatlik idrarda kreatinin klirensi ve mikroalbüminüri parametreleri tekrar çalışıldı. Yoğun bakımda kalış, ekstübasyon ve hastanede kalış süreleri, postoperatif 24 saatlik drenaj miktarları, idrar çıkışları, tüm organ ve sistemlere ait komplikasyonlar, vazodilatör, vazopresör intiyaçları, sıvı ve kan ihtiyacı, antiaritmik kullanım gereksinimleri kaydedildi.

Istatistiksel analizler, Windows için yazılmış SPSS 14.0 programıla (SPSS Inc. Chicago, IL) yapıldı. Gruplar arası karşılaştırmada Mann Whitney-U testi, grup içi ölçüm zamanlarını karşılaştırmada Friedman ve Wilcoxon testleri, oranların karşılaştırılması için de ki-kare testi kullanıldı. Veriler ortalama \pm standart sapma (standard deviation, SD) olarak sunuldu. $\mathrm{p}<0,05$ değerleri istatistiksel olarak anlamlı kabul edildi.

\section{Bulgular}

Iki grup hastaları arasında demografik veriler, yandaş hastalıklar ve kullanılan ilaçlar bakımından fark yoktu. Yine sigara kullanımı da iki grup hastaları arasında benzer

\begin{tabular}{lccc}
\hline \multicolumn{3}{l}{ Tablo 2. Hastaların intraoperatif bulguları (Ortalama \pm SD) } & \\
\hline & Grup K (n=20) & Grup S (n=20) & $\mathrm{p}$ \\
\hline $\begin{array}{l}\text { Aorta klempi } \\
\text { süresi(dakika) }\end{array}$ & $30,4 \pm 11,9$ & $28,7 \pm 9,3$ & 0,712 \\
$\begin{array}{l}\text { Kardiyopulmoner } \\
\text { bypass süresi (dakika) }\end{array}$ & $63,0 \pm 19,8$ & $62,9 \pm 13,7$ & 0,971 \\
$\begin{array}{l}\text { Ameliyat süresi } \\
\text { (dakika) }\end{array}$ & $245,9 \pm 38,5$ & $242,0 \pm 28,3$ & 0,594 \\
$\begin{array}{l}\text { Distal anastomoz } \\
\text { sayısı (n) }\end{array}$ & $3,20 \pm 0,96$ & $2,94 \pm 0,83$ & 0,406 \\
$\begin{array}{l}\text { Defibrilasyon sayısı (n) } \\
\text { Intraoperatif vazopressör } \\
\text { ihtiyacı (n) }\end{array}$ & $1,91 \pm 1,02$ & $1,52 \pm 1,19$ & 0,270 \\
$\begin{array}{l}\text { Intraoperatif vazodilatör } \\
\text { intiyacı (n) }\end{array}$ & $5 / 20$ & $9 / 20$ & 0,368 \\
$\begin{array}{l}\text { Ameliyatta kullanılan } \\
\text { tam kan (Ü) } \\
\text { Intraoperatif kullanılan } \\
\text { toplam kristalloid sıvı } \\
\text { miktarı (ml olarak) }\end{array}$ & $3,54 \pm 0,86$ & $3,7 \pm 0,98$ & 0,347 \\
\hline
\end{tabular}

bulundu ( $p>0,05$; Tablo 1). Iki grubun preoperatif ve postoperatif rutin yapılan laboratuvar bulguları da birbiriyle benzerdi ( $p>0,05)$.

Iki grup hastaları arasında ameliyat, KPB ve aorta klempi süreleri açısından fark saptanmadı ( $p>0,05)$. Distal anastomoz sayıları, ameliyat sırasında kullanılan toplam tam kan miktarları, vazodilatör ve vazopressör ajan gereksinimleri ve aort klempi kalkması sonrası defibrilasyon sayıları gruplar arasında benzerdi ( $p>0,05$; Tablo 2).

Her iki grupta da hastaların T2, T3 ve T4 zamanlarındaki IL-1, IL-6, TNF-alfa ve p-selektin değerleri, T1 zamanındaki değerlere göre anlamlı şekilde yüksek bulundu. Ancak gruplar arasında anlamlı bir fark saptanmadı ( $p>0,05$; Tablo 3).

Postoperatif erken dönemde, yoğun bakımdan çıkışa kadar olan süreçte hiçbir hastamızda organ yetmezliği gelişmedi. Tüm hastalar arasında sadece atorvastatin kullanan 79 yaşında bayan bir hastada reentübasyon gerekli oldu. Ikinci kez entübe edilen hasta 18 saat sonra yeniden ekstübe edildi, yoğun bakımdan 4. günde çıkarıldı ve sorunsuz şekilde 10. günde taburcu edilebildi. Hastaların böbrek fonksiyon testlerinde, idrar çıkış miktarlarında, kreatinin klirenslerinde, postoperatif 6. saat CK-MB ve troponin-I düzeylerinde, postoperatif ilk 24 saatlik yoğun

\begin{tabular}{|c|c|c|c|}
\hline & Grup K ( $n=20)$ & Grup S ( $n=20)$ & $\mathrm{p}$ \\
\hline \multicolumn{4}{|l|}{ IL-1 } \\
\hline T1 & $0,72 \pm 0,66$ & $0,54 \pm 0,34$ & 0,305 \\
\hline T2 & $1,46 \pm 1,00$ & $1,08 \pm 0,64$ & 0,161 \\
\hline T3 & $2,75 \pm 1,40$ & $2,52 \pm 1,53$ & 0,618 \\
\hline T4 & $2,86 \pm 1,28$ & $2,55 \pm 2,90$ & 0,382 \\
\hline \multicolumn{4}{|l|}{ IL-6 } \\
\hline T1 & $10,7 \pm 9,6$ & $9,1 \pm 9,9$ & 0,598 \\
\hline T2 & $44,7 \pm 42,9$ & $51,7 \pm 54,4$ & 0,654 \\
\hline T3 & $138,9 \pm 134,1$ & $164,1 \pm 207,8$ & 0,652 \\
\hline $\mathrm{T} 4$ & $207,1 \pm 87,7$ & $151,7 \pm 190,3$ & 0,349 \\
\hline \multicolumn{4}{|c|}{ TNF-alfa } \\
\hline T1 & $2,06 \pm 0,97$ & $2,44 \pm 1,61$ & 0,378 \\
\hline T2 & $3,93 \pm 3,60$ & $3,65 \pm 2,61$ & 0,779 \\
\hline T3 & $5,46 \pm 4,57$ & $5,74 \pm 2,76$ & 0,815 \\
\hline T4 & $5,41 \pm 3,58$ & $5,32 \pm 3,18$ & 0,935 \\
\hline \multicolumn{4}{|c|}{ p-selektin } \\
\hline T1 & $7,5 \pm 9,9$ & $5,5 \pm 2,7$ & 0,382 \\
\hline $\mathrm{T} 2$ & $5,6 \pm 7,4$ & $5,0 \pm 2,7$ & 0,716 \\
\hline T3 & $8,2 \pm 6,3$ & $9,9 \pm 6,0$ & 0,378 \\
\hline T4 & $13,5 \pm 5,0$ & $7,7 \pm 8,1$ & 0,059 \\
\hline
\end{tabular}

Not: T1: Santral venöz kateter takıldıktan 5 dakika sonra, T2: aort klempinin kalkmasından 5 dakika sonra, T3: KPB'nin sonlandırımasından 10 dakika sonra, T4: ameliyat sonlandıktan 6 saat sonra 
bakım süresince EKG monitörizasyonunda ve hastaların postoperatif nörolojik muayene ve mini mental test skorlarında gruplar arasında fark saptanmadı $(p>0,05)$.

Hastaların postoperatif ekstübasyon ve taburculuk süreleri gruplar arasında benzerdi, fakat yoğun bakım kalış süreleri atorvastatin kullananlarda anlamlı olarak kısa bulundu $(p=0,008)$. Postoperatif dönem de vazodilatör veya vazopressör intiyacı, ilk 24 saatteki toraks drenajı, idrar miktarları ve gerekli olan sıvı ve eritrosit süspansiyonu transfüzyonu miktarları bakımından iki grup arasında istatistiksel olarak anlamlı fark saptanmadı ( $p>0,05$; Tablo 4).

\section{Tartışma}

Preoperatif dönemde atorvastatin kullanımının, koroner arter cerrahisinde kullanılan KPB nedeniyle oluşan inflamasyona ve hastaların perioperatif verileri üzerine olan etkilerini araştırdığımı çalışmamı da, KPB sonrasında oluşan inflamatuar yanıtın gösterilmesi için araştıılan parametrelerde iki grup arasında anlamlı fark saptanmadı. Ancak hastaların postoperatif yoğun bakımda kalış sürelerinin atorvastatin kullananlarda istatistiksel olarak anlamlı şekilde daha kısa olduğu gözlendi.

Kardiyopulmoner bypass'ın birden fazla mekanizma ile inflamasyonu tetiklediği ve bu yolla postoperatif dönemde birçok organ ve sistemin fonksiyonlarını bozduğu gösterilmiştir. Literatürde KPB sonrası salınan proinflamatuar sitokinler (TNF-alfa, IL-1,6,8) gelişen istenmeyen

Tablo 4. Hastaların postoperatif döneme ait özellikleri

(Ortalama \pm SD)

\begin{tabular}{lccc}
\hline & Grup K ( $\mathrm{n}=20)$ & Grup S ( $\mathrm{n}=20)$ & $\mathrm{p}$ \\
\hline $\begin{array}{l}\text { Ekstübasyon } \\
\text { zamanı (saat) }\end{array}$ & $12,1 \pm 3,5$ & $11,6 \pm 4,9$ & 0,683 \\
$\begin{array}{l}\text { Yoğun bakımda } \\
\text { kalış süresi (saat) }\end{array}$ & $72,4 \pm 27,8$ & $56,7 \pm 19,4$ & 0,008 \\
$\begin{array}{l}\text { Hastanede kalış } \\
\text { süresi (gün) }\end{array}$ & $7,8 \pm 2,0$ & $6,9 \pm 1,1$ & 0,434 \\
$\begin{array}{l}\text { Postoperatif Mini } \\
\text { Mental Test Skoru }\end{array}$ & $8,8 \pm 0,8$ & $8,7 \pm 0,7$ & 0,959 \\
$\begin{array}{l}\text { Drenaj miktarı } \\
\text { (mL/24 saat) }\end{array}$ & $870 \pm 539$ & $756 \pm 354$ & 0,752 \\
$\begin{array}{l}\text { ldrar miktarı } \\
\text { (mL/24 saat) }\end{array}$ & $3820 \pm 1239$ & $3775 \pm 1271$ & 0,907 \\
$\begin{array}{l}\text { Postoperatif vazopressör } \\
\text { ihtiyacı (n) }\end{array}$ & $3 / 20$ & $4 / 20$ & 0,408 \\
$\begin{array}{l}\text { Postoperatif vazodilatör } \\
\text { ihtiyacı (n) }\end{array}$ & $4 / 20$ & $7 / 20$ & 0,140 \\
$\begin{array}{l}\text { Postoperatif ilk 24 saatte } \\
\text { toplam sıvı intiyacı (ml olarak) }\end{array}$ & $4087 \pm 1278$ & $4529 \pm 1398$ & 0,303 \\
$\begin{array}{l}\text { Postoperatif eritrosit } \\
\text { süspansiyonu transfüzyonu } \\
\text { gereksinimi (ünite) }\end{array}$ & $0,9 \pm 1,4$ & $0,8 \pm 0,6$ & 0,744 \\
\hline
\end{tabular}

olaylar ile ilişkili bulunmuştur $(1,2)$. Bu nedenle KPB sırasında uygulanabilecek antiinflamatuar stratejiler araştırımış ve proinflamatuar sitokinlerin aktivasyonunu azaltmaya yönelik birçok mekanik ve/veya farmakolojik yöntem denenmiştir. Çalışmamızda da KPB eşliğinde koroner arter cerrahisi geçirecek hastalarda preoperatif dönemde atorvastatin kullanımının inflamasyon ve organ-sistem fonksiyonları üzerine olan etkileri incelendi.

Hindler (17) ve ark. 2006 yılında yayınladıkları çalışmada, preoperatif statin kullanımının, statinlerin pleiotropik etkileri sayesinde kardiyak, vasküler ve nonkardiyak cerrahilerde postoperatif mortaliteyi azalttığını, ancak morbidite üzerine olan etkilerinin değişkenlik gösterdiğini bildirmişlerdir. Benzer olarak, daha çok kalp, aorta, akciğer gibi intratorasik cerrahilerin incelendiği derlemede, preoperatif statin kullanımının greft devamlıı̆ı, hastane kalış süresi, organ disfonksiyonları ve yaşam süreleri üzerinde iyileştirici etkilerinin bulunduğu, ayrıca diğer organ ve sistemlerde gelişebilecek komplikasyonların görülme sıklığlnın da azaldığı belirtilmiştir. Bir başka çalışmada ise statinlerin yüksek doz ACE (Angiotensin Converting Enzyme) inhibitörleriyle beraber yüksek dozda kullanımı ile KPB nedenli inflamasyonun tama yakın azaltılabileceği gösterilmiştir (12-15,18).

Diğer yandan preoperatif dönemde statin kullanımıyla ilgili olarak KPB sonrasında inflamasyonu belli ölçüde azaltsa da mortaliteye etkilerinin bulunmadığını [19], yararlı olduğu belirtilen çalışmaların birden fazla kısıtlayıcı faktörünün bulunduğunu [20], hatta preoperatif kullanımları ile ameliyat sonrası yoğun bakımda takip sırasında özellikle yaşlı hastalarda deliryum tablosunu kolaylaştırdıklarını gösteren çalışmalar da mevcuttur (21).

Florens ve ark. koroner arter cerrahisi geçirecek olan hastalara preoperatif gece ve operasyon sabahı olmak üzere $2 \mathrm{doz} 40 \mathrm{mg}$ atorvastatin vererek inflamasyonu değerlendirdikleri çalışmada yalnızca p-selektin düzeylerinde anlamlı azalma saptadıklarını bildirmişlerdir (5). Bizim çalışmamızda bu çalışmadan farklı olarak, hastalar en kısa 3 ay olacak şekilde statin kullanmaktaydılar ve ameliyat günü de statin dozlarını aldılar. Ancak adı geçen çalışmada hastalar $34^{\circ} \mathrm{C}^{\prime}$ ye kadar soğutulmuşken, bizim çalışmamızda hastalar $28-30^{\circ} \mathrm{C}^{\prime}$ de ameliyat edildiler. Sonuçta çalışmamızda inflamasyonu değerlendirmek amacıyla baktığımız parametreler (IL-1, IL-6, TNF-alfa ve p-selektin) kontrol değerlerine göre anlamlı şekilde artarken bu artış kontrol ve atorvastatin gruplarında birbiriyle benzerdi ( $p>0,05)$.

Literatürde statin kullanımına bağlı olarak karaciğer fonksiyon testlerinde artış ve kas güçsüzlüğü olabileceği bildirilmiştir (22). Bu nedenle preoperatif medikasyonun azaltılması ve olası yan etkilerden kaçınılması düşüncesiyle statin grubu ilaçların preoperatif dönemde bırakılması söz konusu olabilmektedir. Iki grup karşılaştıııldığında postoperatif ALT, AST, GGT, ALP, bilirubin ve PTZ değer- 
leri arasında anlamlı fark yoktu. Ayrıca CK değerleri ve ekstübasyon zamanı bakımından gruplar benzer bulundu. Karaciğer fonksiyon testlerinde artış ve kas güçsüzlüğü görülmemesi, ekstübasyon süresinin istatistiksel olarak anlamsız da olsa statin grubunda daha kısa olması böylesi yan etkilerin statin grubu ilaçların preoperatif dönemde kesilmesine gerekçe olamayacağının bulgusu olarak değerlendirilebilir.

Chen ve ark.'nın ratlar (23) ve benzer olarak Lazar ve ark.'nın domuzlar üzerinde (15) yaptıkları çalışmalarda, preoperatif statin kullanımının koroner iskemi/reperfüzyon hasarında oluşan aritmi insidansını azalttığı, ekokardiyografik bulguları iyileştirdiği, oluşan infarkt alanını küçülttüğü ve medikal tedaviye yanıtı artırdığı belirtilmiştir. Bizim çalışma grubumuzda postoperatif infarktüs ve yetersizlik gelişen hastamı olmadı. Ancak atorvastatin alan hastalarda, KPB sonrasında kalbin yeniden çalıştırılması için istatistiksel olarak anlamlı olmamasına rağmen daha az defibrilasyon gerekti ( $p>0,05)$.

Statinlerin klinik kullanımının artması ile kardiyovasküler olaylara ikincil gelişebilen MI, SVO, renal disfonksiyon ve ölüm gibi komplikasyonlarda azalma sağlanmıştır. Statinler bu etkilerini, antihiperkolesterolemik özelliklerine ek olarak gösterdikleri antiinflamatuar ve immünomodulatuar özellikleri ile gerçekleştirirler $(12,15)$. Pan ve ark. (12) KPB desteğinde koroner bypass yapılan hastalarda preoperatif statin kullanımını değerlendirdikleri retrospektif araştırmada, preoperatif statin tedavisi almanın postoperatif dönemde $\mathrm{Ml}$, kardiyak aritmi, inme ve renal disfonksiyon için olmasa da, postoperatif ilk 1 aylık tüm nedenlere bağlı mortalitenin azalması için bağımsız etkin faktör olduğunu belirtmişlerdir. Bizim çalışma grubumuzda mortalite olmadı. Ayrıca postoperatif erken dönemde hiçbir hastamızda organ yetmezliği gelişmedi. Sadece atorvastatin grubundan 1 hastada re-entübasyon gerekli oldu. Ikinci kez entübe edilen hasta 18 saat sonra yeniden ekstübe edildi ve sorunsuz şekilde taburcu edilebildi. Çalışmamızda postoperatif dönemde hastaların böbrek fonksiyon testlerinde, idrar çıkış miktarlarında, kreatinin klirenslerinde, postoperatif 6. saat CK-MB ve troponin-I düzeylerinde, postoperatif ilk 24 saatlik yoğun bakım süresince EKG monitörizasyonunda ve hastaların postoperatif nörolojik muayene ve mini mental test skorlarında gruplar arasında fark saptanmadı $(p>0,05)$.

Íki grup karşılaştırıldığında postoperatif erken dönem komplikasyonlar açısından anlamlı fark bulunmadı. Ancak, ekstübasyon zamanı ve hastaneden taburculuk zamanları gruplar arasında birbirine benzerken, yoğun bakım süreleri statin kullanan hastalarda anlamlı olarak daha kısa bulundu. Yoğun bakımda kalış süreleri ve postoperatif komplikasyonlar beraber değerlendirildiğinde, gruplar kendi aralarında benzer bulunmasına karşın, preoperatif dönemde atorvastatin kullanım sürelerinin ve kullanılan dozların standart olmaması, bunun yanında hasta sayısının azlığı bu çelişkinin nedeni olabilir.
Majör cerrahi travmaya ek olarak KPB sırasında immün hücrelerin ve proteinlerin membran oksijenatör ve pompalardan geçişi sırasında hücrelerde yıkım, kompleman aktivasyonu ve nötrofil ve lenfositlerde fonksiyonel değişiklikler olmaktadır. Kompleman kaskadı ve immün hücrelerin aktivasyonunun yanı sıra inflamatuar mediyatörlerin salınımı doku hasarına neden olur ve bu da postoperatif organ disfonksiyonunun başlıca nedenidir $(1,3,4,8)$. Kardiyopulmoner bypass eşliğinde koroner arter cerrahisi yapılan hastalarda, postoperatif dönemde plazma inflamatuar parametrelerinde anlamlı yükselme olduğu gösterilmiştir (1-3). Çalışmamızda da hastaların IL1, IL-6, TNF-alfa ve p-selektin seviyeleri postoperatif dönemde, bazal değerlerle kıyaslandığında anlamlı olarak yükselme gösterdi. Ancak bu yükselme, statin kullanan hastalar ve kontrol grubu hastalarda benzerdi. Ayrıca postoperatif dönem komplikasyonları bakımından da gruplar arasında fark saptanmadı.

Çalışmamızda hasta sayısının proinflamatuar parametreler için yeterli bulunmasına rağmen, hasta sonuçları (morbidite ve mortalite) için az olması, hastaların preoperatif dönemde kullandıkları atorvastatin dozlarının ve preoperatif kullanım sürelerinin standardize olamaması, greft ve miyokard fonksiyonlarının değerlendirilmemesi ve uzun dönem sonuçların takip edilememiş olması gibi kısıtlılıkları bulunduğunu düşünmekteyiz.

Sonuç olarak; çalışmamız da koroner arter cerrahisi geçirecek olan hastalarda preoperatif atorvastatin kullanımı ile postoperatif komplikasyonlar arasında anlamlı bir ilişki saptanmadı. IL-1, IL-6, TNF-alfa ve p-selektin seviyeleri gruplar arasında fark göstermezken, ameliyat sonrası dönemde bazal değerlerden anlamlı olarak yüksek bulundu. Ancak statin kullanan hastalarda postoperatif dönem yoğun bakımda kalış süresi kontrol grubuna oranla anlamlı olarak kısa bulundu. Perioperatif komplikasyonlar ve laboratuvar değerleri ile yoğun bakımda kalış süresinin kısalığı arasında anlamlı bir bağlantı kurulamadı. Ancak sonucun klinik önemi düşünüldüğünde, bulguların ileri çalışmalarla desteklenmesi gerektiğini düşünmekteyiz.

\section{Kaynaklar}

1. Laffey JG, Boylan JF, Cheng DC. The systemic inflammatory response to cardiac surgery. Anesthesiology 2002;97:215-52.

2. Sablotzki A, Dehne MG, Mann V, Görlach G, Mühling J, Zickmann $B$, et al. Plasma levels of selectins and interleukins in cardiovascular surgery using cardiopulmonary bypass. Thorac Cardiovasc Surg 1999;47:26-31

3. Paparella D, Yau TM, Young E. Cardiopulmonary bypass induced inflammation; pathophysiology and treatment. An update. Eur J Cardiothorac Surg 2002;21:232-44.

4. Larmann J, Theilmeier G. Inlammatory response to cardiac surgery: cardiopulmonary bypass versus noncardiopulmonary bypass surgery. Best Pract Res Clin Anaesthesiol 2004;18;425-38.

5. Florens E, Salvi S, Peynet J, Elbim C, Mallat Z, Bel A, et al. Can statins reduce the inflammatory response to cardiopulmonary bypass? A clinical study. J Card Surg 2001;16:232-9. 
6. Brix-Christensen V. The systemic inflammatory responses after cardiac surgery with cardiopulmonary bypass in children. Acta Anaesthesiol Scand 2001;45:671-9.

7. Çelebioğlu B, Özer E. Kardiyopulmoner bypass ve sistemik inflamatuvar yanıt. Hacettepe Tip Dergisi 2004;35:18-26.

8. Wan S, Le Clerc JL, Vincent JL. Inflammatory response to cardiopulmonary bypass, mechanisms involved and possible therapeutic strategies. Chest 1997;112:676-92.

9. Temple R. The challenge of regulating, development and approval of drugs with pleiotropic action in cardiovascular disease. Am J Cardiol 1988;81:5-9.

10. Bellosta S, Ferri N, Arnaboldi L, Bernini F, Paoletti R, Corsini A. Pleiotropic effects of statins in atherosclerosis and diabetes. Diabetes Care 2000;Suppl:2:72-8.

11. Callahan AS 3rd. Vascular pleiotropy of statins: clinical evidence and biochemical mechanism. Curr Atheroscler Rep 2003;5:33-7.

12. Pan W, Pintar T, Anton J, Lee W, Vaughn WK, Collard CD. Statins are associated with a reduced incidence of perioperative mortality after coronary artery bypass graft surgery. Circulation 2004;110(Supl II):45-9.

13. Lazar HL. Role of statin therapy in the coronary bypass patient. Ann Thorac Surg 2004;78:730-40.

14. Werba JP, Tremoli E, Massironi P, Camera M, Cannata A, Alamanni $F$, et al. Statins in coronary bypass surgery: rationale and clinical use. Ann Thorac Surg 2003;76:2132-40.

15. Lazar HL, Bao Y, Zhang Y, Bernard SA. Pretreatment with statins enhances myocardial protection during coronary revascularization. J Thorac Cardiovasc Surg 2003;125:1037-42.
16. Folstein MF, Folstein SE, McHugh PR. "Mini Mental State" A practical method for grading the cognitive state of patients for the clinician. J Psychiatr Res 1975\$12:189-98.

17. Hindler K, Shaw AD, Samuels J, Fulton S, Collard CD, Riedel B. Improved postoperative outcomes associated with preoperative statin therapy. Anesthesiology 2006;105:1260-72.

18. Radaelli A, Loardi C, Cazzaniga M, Balestri G, DeCarlini C, Cerrito $M G$, et al. Inflammatory activation during coronary artery surgery and its dose-dependent modulation by statin/ACE-inhibitor combination. Arterioscler Thromb Vasc Biol 2007;27:2750-5.

19. Imtiaz SA, Buth KJ. Preoperative statin use and in-hospital outcomes following heart surgery in patients with unstable angina. Eur J Cardiothorac Surg 2005;27;1051-6.

20. Morgan C, Zapitelli M, Gill P. Statin prophilaxis and inflammatory mediators follaowing cardiopulmonary bypass: a systematic review. Crit Care 2009:13:165.

21. Mathew JP, Grocott HP, McCurdy JR, Ti KL, Davis RD, Laskowitz DT, et al. Preoperative statin therapy does not reduce cognitive dysfunction after cardiopulmonary bypass. J Cardiothorac Vasc Anesth 2005;19:294-9.

22. Bellosta S, Paoletti R, Corsini A. Safety of statins: focus on clinical pharmacokinetics and drug interactions. Circulation 2004;109(suppl III):50-7.

23. Chen J, Nagasawa Y, Zhu BM, Ohmori M, Harada K, Fujimura A et al. Pravastatin prevents arrhythmias induced by coronary artery ischemia/reperfusion in anesthetized normocholesterolemic rats. J Pharmacol Sci 2003;93;87-94. 